\title{
Lugar do corpo na clínica ${ }^{117}$
}

\section{Miguel Calmon du Pin e Almeida ${ }^{118}$}

\begin{abstract}
"O homem é essencialmente necessitado de ajuda, por estar sempre em perigo de se perder, de não conseguir lidar consigo. Este perigo é ligado à liberdade do homem. Toda a questão do poder-serdoente está ligada à imperfeição de sua essência. Toda a doença é uma perda de liberdade, uma limitação da possibilidade de viver"119.
\end{abstract}

A história do pensamento ocidental está marcada desde seus começos pelas repetidas e sucessivas advertências contra o impulso de determinar, definir e controlar a vida sob o risco de acabar com a vida. São pseudoquestões aquelas questões que pretendem, uma vez respondidas, acabar definitivamente com a possibilidade de seguir perguntando. As respostas destas pseudoquestões, ou melhor a impossibilidade de suas respostas, já estão contidas na pergunta. Isso porque as questões, quando respondidas, só se fazem enriquecer com as respostas que lhes são oferecidas. Incrementam a capacidade de perguntar.

O positivismo do século XIX não fez outra coisa senão acentuar a procura do sentido único, destituindo de valor os campos da poesia, da infância e do jogo e do divertimento, e reduzindo tudo à razão e à ciência. É neste contexto que a psicanálise se insere como um pensamento da desrazão.

E de tempos em tempos, este esforço de reduzir tudo ao estatuto da razão e do sentido único, muda de lugar, inclusive na psicanálise. Por exemplo, hoje, "quando a razão está em crise, quando julgamos como racionalizações os conceitos simples e a mente é incapaz de guiar os atos individuais e o processo social, viramo-nos para o corpo e seus interesses como caminho de ser e do tornar-se. O corpo se torna a superfície privilegiada para a inscrição de sentidos $^{120 ”}$.

\footnotetext{
${ }_{117}$ Trabalho apresentado na mesa "Fenomenologia e Psicanálise: o lugar do corpo na clínica " no II Simpósio Bienal SBPSP "Fronteiras da Psicanálise: a clínica em movimento" no dia 29 de agosto de 2020.

118 Membro efetivo da Sociedade Brasileira de Psicanálise do Rio de Janeiro da qual foi presidente, atual diretor do Instituto da SBPRJ, editor regional da RBP.

${ }^{119}$ Heidegger, Martin - Seminários de Zollikon, Ed. Vozes, Petrópolis, 2001, pg. 180.

120 Villaça, Nízia - A edição do corpo: tecnociência, artes e moda. Estação das Letras, Rj, 2007, pg
} 
Assim, nesta espécie de retração de sentidos, indo dos mais complexos para os mais simples, o corpo, como expressão da manifestação mais próxima da natureza do homem, toma o lugar do elemento o mais primário do humano, último reduto do humano, último lugar de ancoragem para dar sentido à experiência humana, como superfície elementar onde se dispõe o humano do homem, como se o corpo pudesse ser reduzido às suas funções fisiológicas, "naturais", configurando mais um engano provocado pelo impulso de estabelecer as causas das coisas do mundo, como nos mostra Nízia Villaça em seu livro "Edição do Corpo: tecnociência, artes e moda", publicado pela Estação das Letras. A autora evidencia em sua reflexão que, tal como a cultura, o corpo também é editado, corpo é relação, corpo é ser-com, sem que se possa tomá-lo ou reduzi-lo simplesmente a um elemento da natureza.

Tomar e aceitar a vida humana, logo o corpo libidinal, como uma dinâmica e um processo é o que nos está continuamente sendo exigido, ao estilo da melhor e mais fecunda definição de pulsão no texto de Freud, isto é, uma "contínua exigência de trabalho".

E são muitas as formas de mascaramento da busca por uma cristalização desta dinâmica.

Martin Heidegger, nos "Seminários de Zollikon", nos adverte que apesar do fisiológico "ser condição necessária para a possibilidade de uma relação humana com o outro, (...) não há um órgão sensorial para aquilo que se chama "o outro"”. Prossegue afirmando que o fisiológico "não é uma condição suficiente no sentido literal da palavra "alcançar", de que ele não pode alcançar o espaço até $o$ outro e constituir uma relação ${ }^{121 "}$.

Isso significa que objeto, sujeito e a possibilidade de sua relação se constituem mutuamente, sem que se possa aceitar a pré-existência de um sobre o outro. Por isso podemos dizer que o conceito de unidade é o resultado do processo de constituição do si-mesmo. Representar o "um" tem como précondição para sua vigência, a identidade e a diferença.

A meu ver, o fundamental a ser retido aqui é a dinâmica, é o que mantém e possibilita estar constantemente em jogo. Não deixar a peteca cair, manter a bola em jogo. Não há ponto de partida nem muito menos ponto de chegada. Ser

${ }^{121}$ Heidegger, Martin - Seminários de Zollikon, ed. Vozes, 2001, p. 178. 
um sujeito não se reduz a um substantivo, assim como seu corpo não se reduz à sua materialidade. Ao mesmo tempo e por outro lado, não é também uma articulação de sentidos e afetos que uma vez alcançada não se possa perder mais. Pelo contrário, é um estar permanentemente em jogo, permanentemente em questão, disposto ao confronto com tudo aquilo que convida ao fora do jogo, fora do desejo, fora de questão. Ser sujeito, assim como seu corpo, é aceitar e se inscrever nesta dinâmica.

A correlação do soma com o "outro" e, logo, corpo pulsional é o que nos toca entender. Como se dá a soldagem entre estes elementos? Como se constitui o corpo pulsional, libidinal?

Os filólogos dizem que o étimo "psi" vem de uma onomatopeia que descreve o sopro divino. O sopro libidinal do outro semelhante que anima a pulsão, logo o corpo, e que lhe dá vida anímica. Não me certifiquei da exatidão desta hipótese etimológica, mas fico com os poetas. Eles com certeza concordariam.

Assim chegamos a nossa questão: qual o lugar do corpo na clínica? Mais propriamente, na clínica on-line, esta que a pandemia nos exige?

Não nos é estranho que o ambiente de nossos consultórios seja tomado como extensão do corpo dos psicanalistas. Em sua pulsionalidade, corpo do psicanalista abrange não apenas a materialidade de seu físico, mas também suas expressões, a decoração de seu consultório, a forma com que recebem seus analisandos, se os levam até a porta para se despedir, se os cumprimentam dando a mão ou com beijinhos, seu tom de voz, as inflexões de sua voz, a ponta de seu sapato visto do divã... tudo isso é corpo do psicanalista em sua dimensão pulsional.

O setting compõe em seu conjunto o corpo libidinal do analista, isto é, aquilo que de si ele oferece para seus pacientes reencenarem seus dramas pessoais. A forma como os acolhe. Como as impressões digitais, não há dois settings iguais, tal como não há dois corpos iguais.

Mais ainda, nossos corpos são modificados em função dos modos de relação que estabelecemos com cada paciente. Cada um deles, recorta e toma para si, um pedaço singular do playground que dispomos para se analisarem.

Como tudo isso se altera e agita com os análises on-line? Não somos mais os únicos que os recebem em "nossas casas”. Agora nossos pacientes nos recebem 
em suas casas. Não mais no ambiente cuidadosamente preparado por nós para recebermos nossos pacientes, mas na intimidade de suas casas. Nas salas onde convivem com suas famílias, em seus quartos, dentro de seus carros buscando alguma privacidade...

Setting é corpo. Corpo libidinal. Corpo do psicanalista e relação com seu analisando. Ou somente é cabeça, tronco e membros. Somente decoração.

E diante destas mudanças virtuais, como a representação de nossos corpos fica afetada?

Vou deixar as perguntas nas bordas do texto e me deixar embalar pelo espírito um tanto filosófico de Além do Princípio do Prazer, para dizer que o homem não cessa de se produzir, que o humano do homem está em contínua construção, inacabado e imperfeito que é. A citação de Heidegger que escolhi como epigrafe está nesta direção: “O homem é essencialmente necessitado de ajuda, por estar sempre em perigo de se perder, de não conseguir lidar consigo. Este perigo é ligado à liberdade do homem. Toda a questão do poder-ser-doente está ligada à imperfeição de sua essência. Toda a doença é uma perda de liberdade, uma limitação da possibilidade de viver”. Se no que alcança quando repete, o homem encontrasse tudo quanto necessita, ele estaria acabado. No que se repete, o homem se reassegura do que é e se espanta e se abre para o que não é. Simultaneamente se reassegura do que tem e se espanta e se abre para o que não tem. A cada uma das vezes em que repete, algo faz diferença, e é em torno da capacidade de suportar e reconhecer esta diferença que um sujeito terá que se constituir.

Rio de Janeiro, 19 de junho de 2020. 